\title{
Commercial Absorption Heat Pump Water Heater: Beta Prototype Evaluation
}

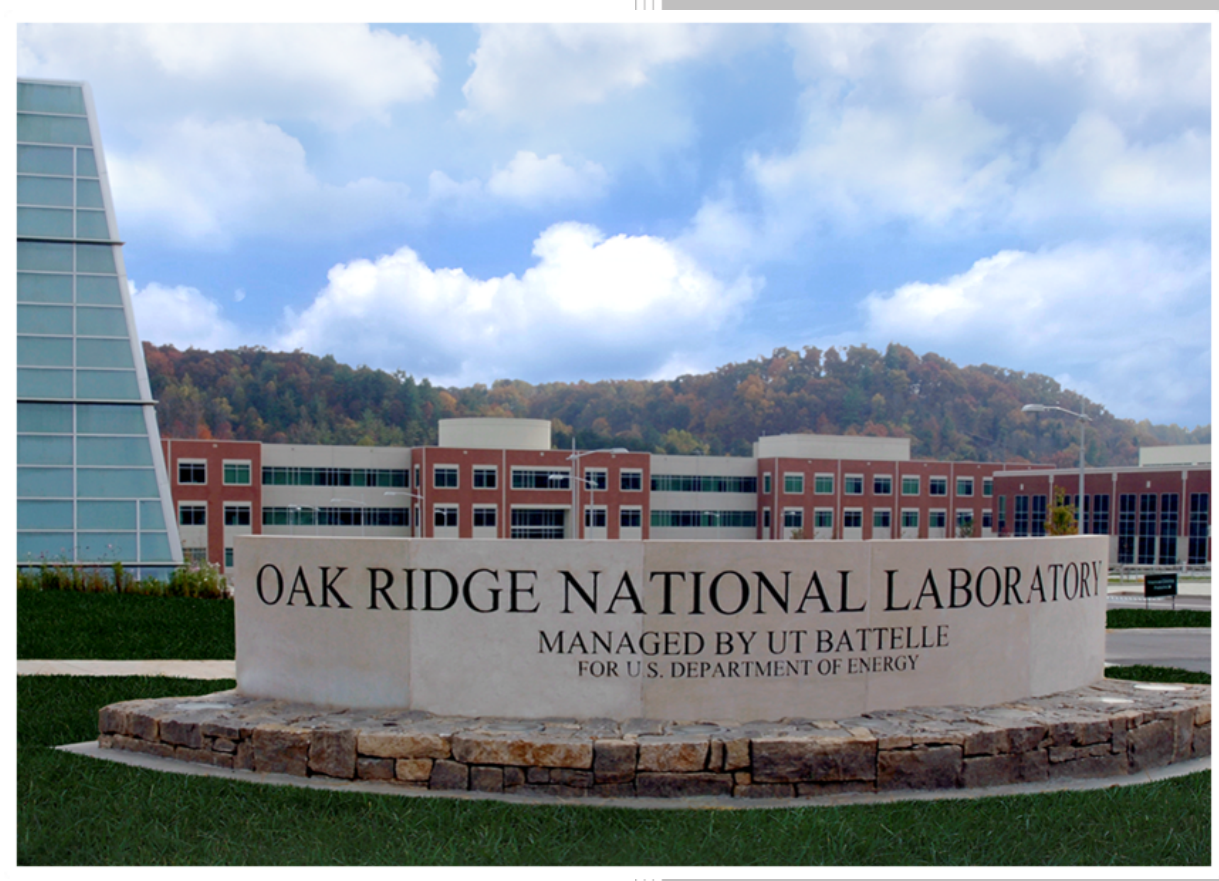

Patrick Geoghegan Moonis Ally

Vishaldeep Sharma

$10 / 14 / 2016$ 


\title{
DOCUMENT AVAILABILITY
}

Reports produced after January 1, 1996, are generally available free via US Department of Energy (DOE) SciTech Connect.

Website http://www.osti.gov/scitech/

Reports produced before January 1, 1996, may be purchased by members of the public from the following source:

\author{
National Technical Information Service \\ 5285 Port Royal Road \\ Springfield, VA 22161 \\ Telephone 703-605-6000 (1-800-553-6847) \\ TDD 703-487-4639 \\ Fax 703-605-6900 \\ E-mail info@ntis.gov \\ Website http://www.ntis.gov/help/ordermethods.aspx
}

Reports are available to DOE employees, DOE contractors, Energy Technology Data Exchange representatives, and International Nuclear Information System representatives from the following source:

Office of Scientific and Technical Information

PO Box 62

Oak Ridge, TN 37831

Telephone 865-576-8401

Fax 865-576-5728

E-mail reports@osti.gov

Website http://www.osti.gov/contact.html

This report was prepared as an account of work sponsored by an agency of the United States Government. Neither the United States Government nor any agency thereof, nor any of their employees, makes any warranty, express or implied, or assumes any legal liability or responsibility for the accuracy, completeness, or usefulness of any information, apparatus, product, or process disclosed, or represents that its use would not infringe privately owned rights. Reference herein to any specific commercial product, process, or service by trade name, trademark, manufacturer, or otherwise, does not necessarily constitute or imply its endorsement, recommendation, or favoring by the United States Government or any agency thereof. The views and opinions of authors expressed herein do not necessarily state or reflect those of the United States Government or any agency thereof. 
Energy and Transportation Sciences Division

\title{
COMMERCIAL ABSORPTION HEAT PUMP WATER HEATER: BETA PROTOTYPE EVALUATION
}

\author{
Patrick Geoghegan \\ Moonis Ally \\ Vishaldeep Sharma
}

Date Published: 10/14/2016

Prepared by

OAK RIDGE NATIONAL LABORATORY

Oak Ridge, TN 37831-6283

managed by

UT-BATTELLE, LLC

for the

US DEPARTMENT OF ENERGY

under contract DE-AC05-00OR22725 



\section{CONTENTS}

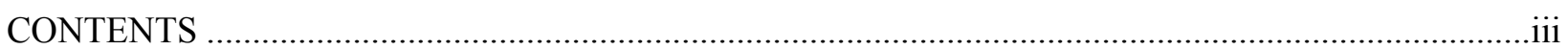

ABSTRACT …

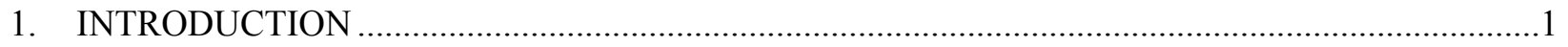

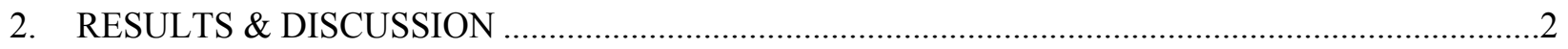

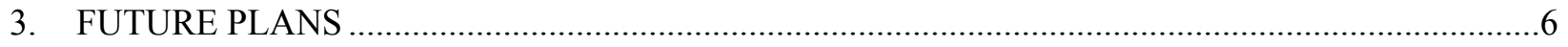




\begin{abstract}
The Beta version of the Commercial Absorption Heat Pump (CAHP) water heater was evaluated in the environmental chambers at Oak Ridge National Laboratory. Ambient air conditions ranged from 17 to 75 ${ }^{\circ} \mathrm{F}$ and inlet water temperatures ranged from 100 to $120^{\circ} \mathrm{F}$ in order to capture trends in performance. The unit was operated under full fire $(100 \%)$ and partial fire $(55 \%)$. The unit was found to perform at $90 \%$ of the project goal at the design conditions of $47^{\circ} \mathrm{F}$ ambient and $100^{\circ} \mathrm{F}$ water temperatures. The trends across the full range of environmental conditions were as expected for ambient air temperatures above $32^{\circ} \mathrm{F}$. Below this temperature and for the full fire condition, frost accumulated on the evaporator coil. In future work a defrost strategy will be enabled, the unit will be thoroughly cleaned of an oil contamination and the rectifier will be reconfigured in order to meet the design goals and have a field test unit ready in early 2017.
\end{abstract}

\title{
1. INTRODUCTION
}

This document presents the results of our evaluation of the $140 \mathrm{kBtu} / \mathrm{h}$ commercial absorption heat pump water heater Beta prototype unit. The Beta is the third generation configuration in this project. The lab breadboard test system was the first prototype and was a culmination of intense modeling efforts by Stone Mountain Technologies, Inc. (SMTI) and ORNL. The second prototype was named the Alpha and consisted of many of the breadboard components, improvements to a number of heat exchangers and assembled as a package unit. The Beta contains a number of further improvements over the Alpha. It is considerably smaller than the Alpha prototype with a $30 \%$ reduction in volume as well as a $23 \%$ smaller footprint. Five of the eight heat exchangers in the Beta are smaller and less costly. The evaporator fan, motor and venturi design were all upgraded. The solution pump was also improved.

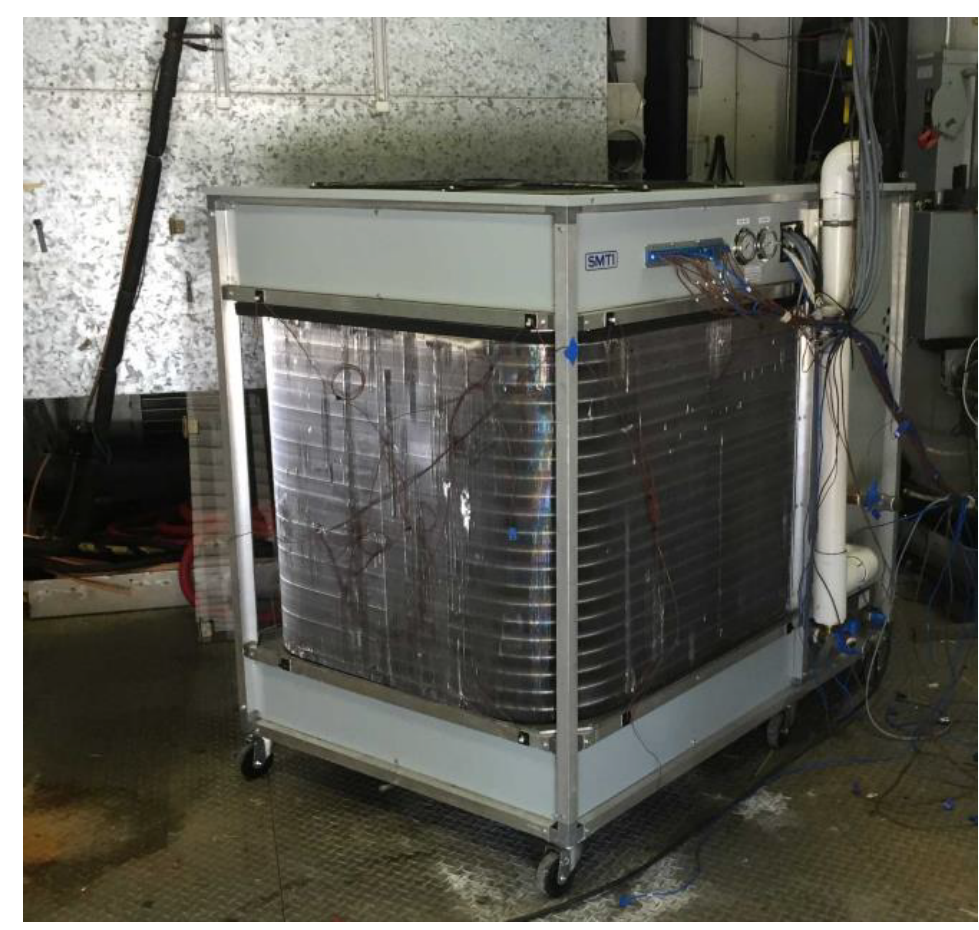

Figure 1: Beta unit in the environmental chamber at ORNL 


\section{RESULTS \& DISCUSSION}

The performance of the Beta is described in terms of the gas input based Coefficient of Performance $\left(\mathrm{COP}_{\text {gas }}\right)$ and the heat load duty. The former is defined as

$$
\begin{aligned}
C O P_{\text {gas }}= & \frac{\text { Sensible water heat load }}{\text { Maximum energy available from the natural gas }} \\
& =\frac{\dot{m}_{w} c_{p w}(\text { water temperature increase })}{\dot{V}_{g a s} h_{h v}}
\end{aligned}
$$

where

$\dot{m}_{w} \quad$ water mass flow rate, $\mathrm{lb} / \mathrm{h}$

$c_{p w} \quad$ specific heat capacity, Btu/lb ${ }^{\circ} \mathrm{F}$

$\dot{V}_{\text {gas }} \quad$ volumetric flow of gas to the burner, $\mathrm{ft}^{3} / \mathrm{h}$

$h_{h v} \quad$ natural gas higher heating value, $\mathrm{Btu} / \mathrm{ft}^{3}$

and temperatures are in ${ }^{\circ} \mathrm{F}$.

Figures 2 and 3 are plots of $\mathrm{COP}_{\text {gas }}$ and heat duty for a range of ambient $\left(17-75^{\circ} \mathrm{F}\right)$ and hydronic $(100-$ $120^{\circ} \mathrm{F}$ ) temperatures investigated by ORNL with the unit operating at $100 \%$ firing rate. The plots show that the system performance experiences the expected trends for the range of conditions investigated.

Performance decreases with increased hydronic temperature and decreased ambient temperature. The data recorded at the $47 / 100^{\circ} \mathrm{F}$ design point indicates that the system is performing at $90 \%$ of design $\mathrm{COP}_{\text {gas }}$ ( $~ 1.32$ vs. the design goal of 1.45$)$ and design water heating output or heat duty $(\sim 126 \mathrm{kBtu} / \mathrm{h}$ vs. design goal of $140 \mathrm{kBtu} / \mathrm{h}$ ). Figure 2 also contains $47 / 100^{\circ} \mathrm{F}$ and $47 / 105^{\circ} \mathrm{F}$ data recorded at SMTI. The data has slightly higher COP values than the experimental data recorded at ORNL. Airflow blockage through the evaporator to simulate lower ambient temperatures led to secondary effects that contributed to this discrepancy.

Curve fits to the 75,60 and $47^{\circ} \mathrm{F}$ data all follow the same slope while curve fits to the 32 and $17^{\circ} \mathrm{F}$ data follow a slightly different slope due to frost accumulation on the coil (see Figure 4). A future defrost mechanism will alleviate this problem. 


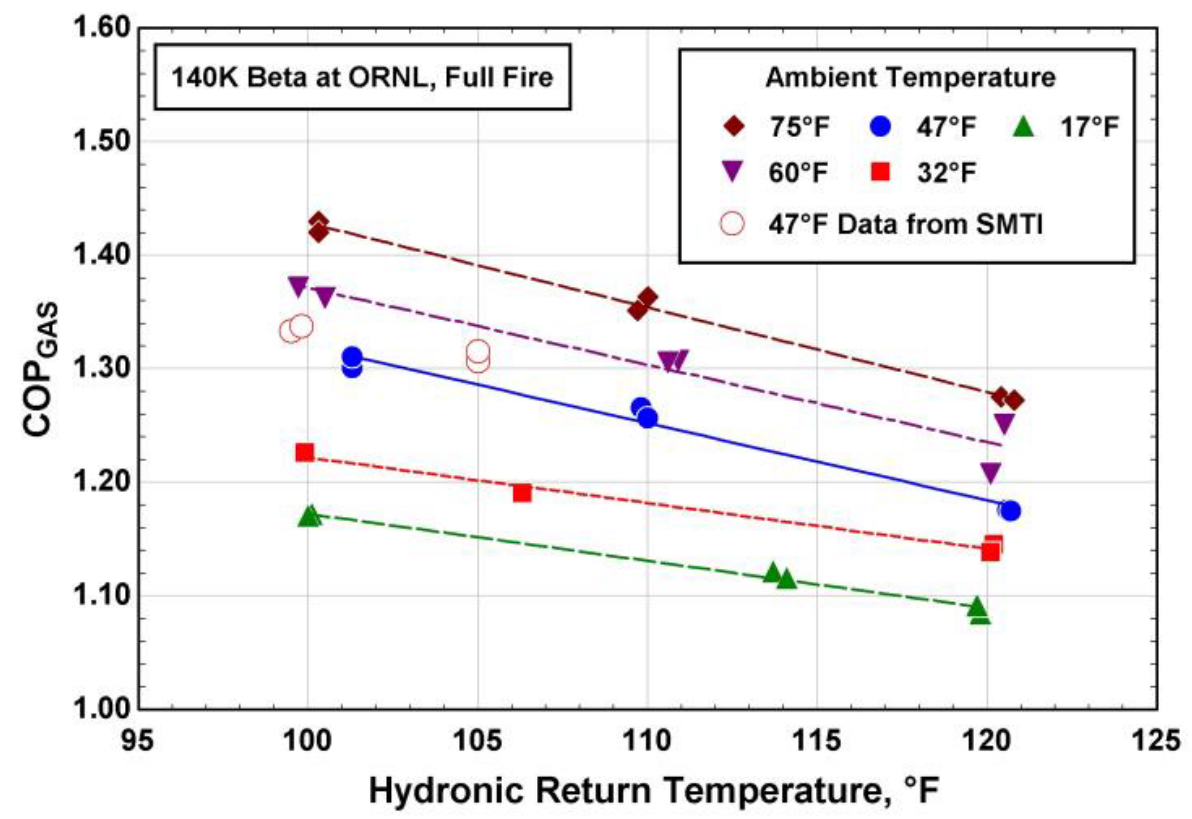

Figure 2. $\mathrm{COP}_{\text {gas }}$ vs ambient air and hydronic temperatures

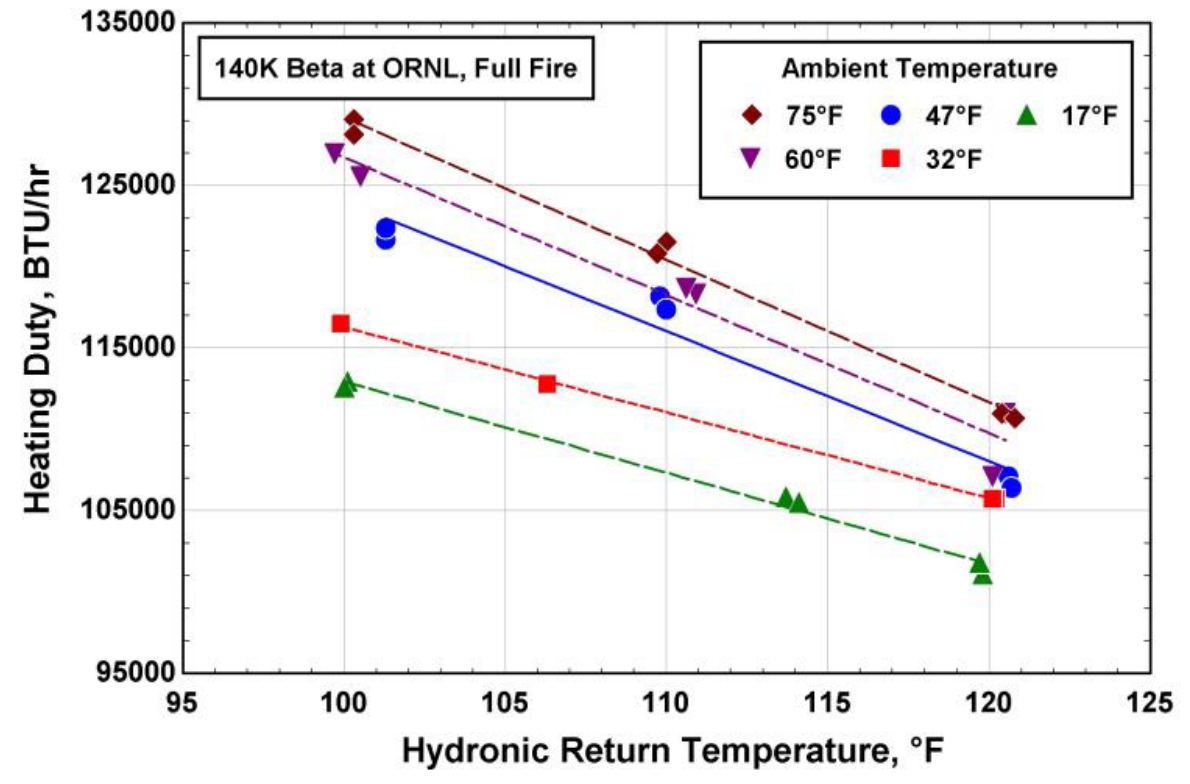

Figure 3. Heating load vs ambient and hydronic temperatures 


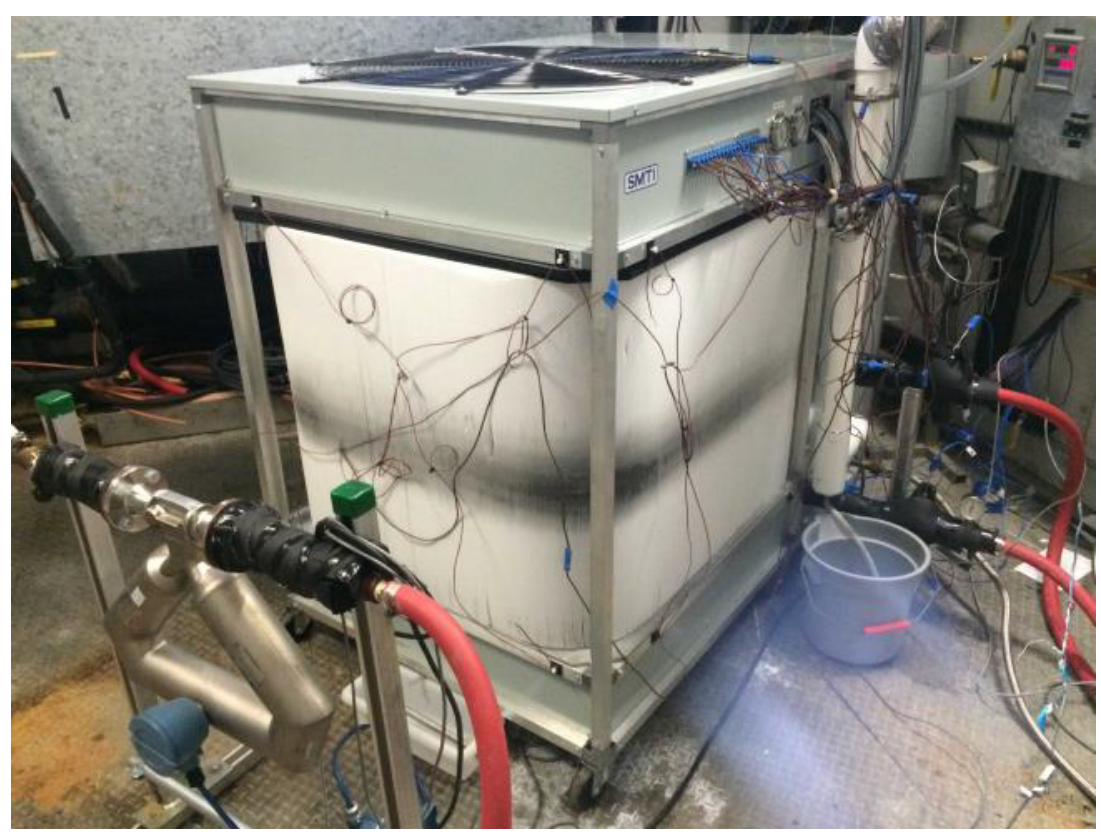

Figure 4. 140k Beta unit with a frosted evaporator coil

The unit was also investigated at a reduced firing rate of $55 \%(54 \mathrm{kBtu} / \mathrm{h})$ for a range of ambient air $(17$ $\left.60^{\circ} \mathrm{F}\right)$ and hydronic $\left(100-120^{\circ} \mathrm{F}\right)$ temperatures. This testing was performed to evaluate system performance and heating duty at lower firing rates and demonstrate capacity modulation characteristics.

Figures 5 and 6 show performance trends similar to those experienced during the $100 \%$ fire testing. At the design conditions of $47 / 100^{\circ} \mathrm{F}$ the system provides a $\mathrm{COP}_{\text {gas }}$ of $\sim 1.32$. The impact on performance due to the accumulation of frost is less noticeable for the $55 \%$ firing rate data. This is expected as the heat transferred by the evaporator is reduced by roughly $50 \%$ compared to that at full firing rate and the time required for frost to accumulate would be longer. 


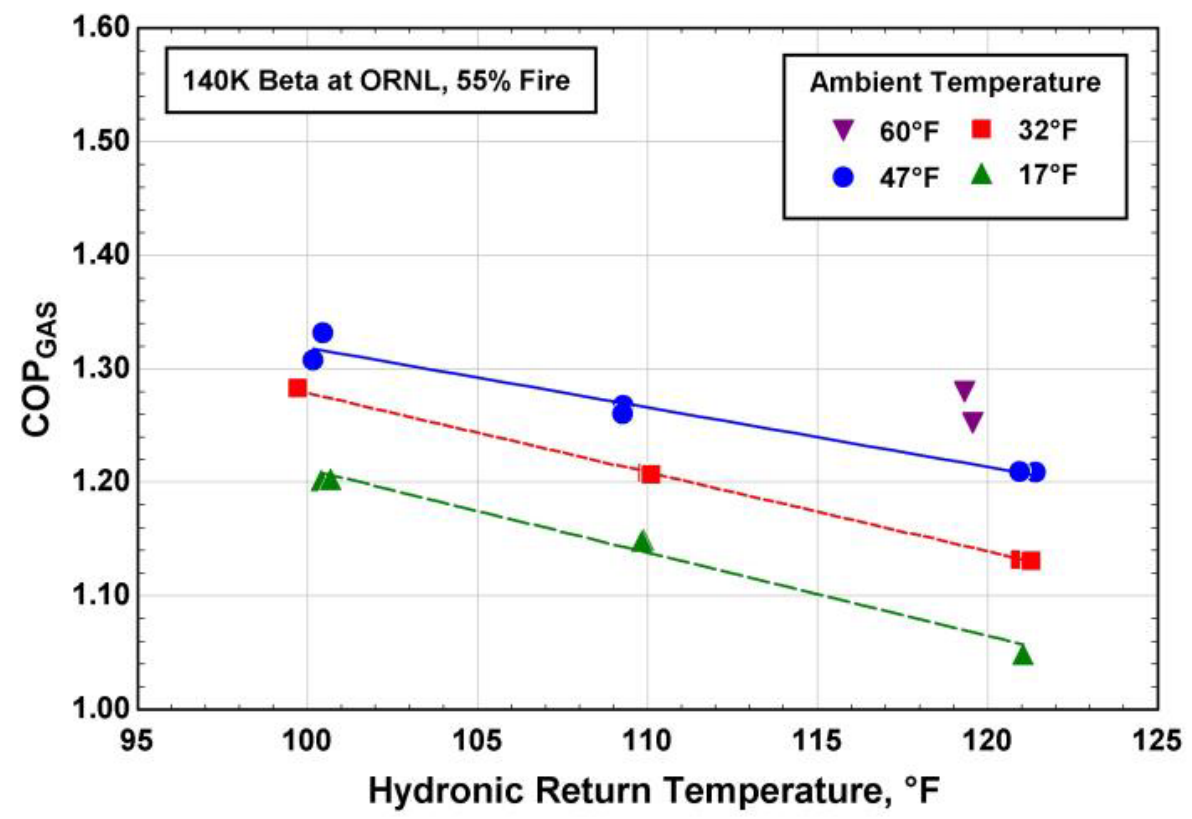

Figure 5. $\mathrm{COP}_{\text {gas }}$ vs ambient air and hydronic inlet temperatures

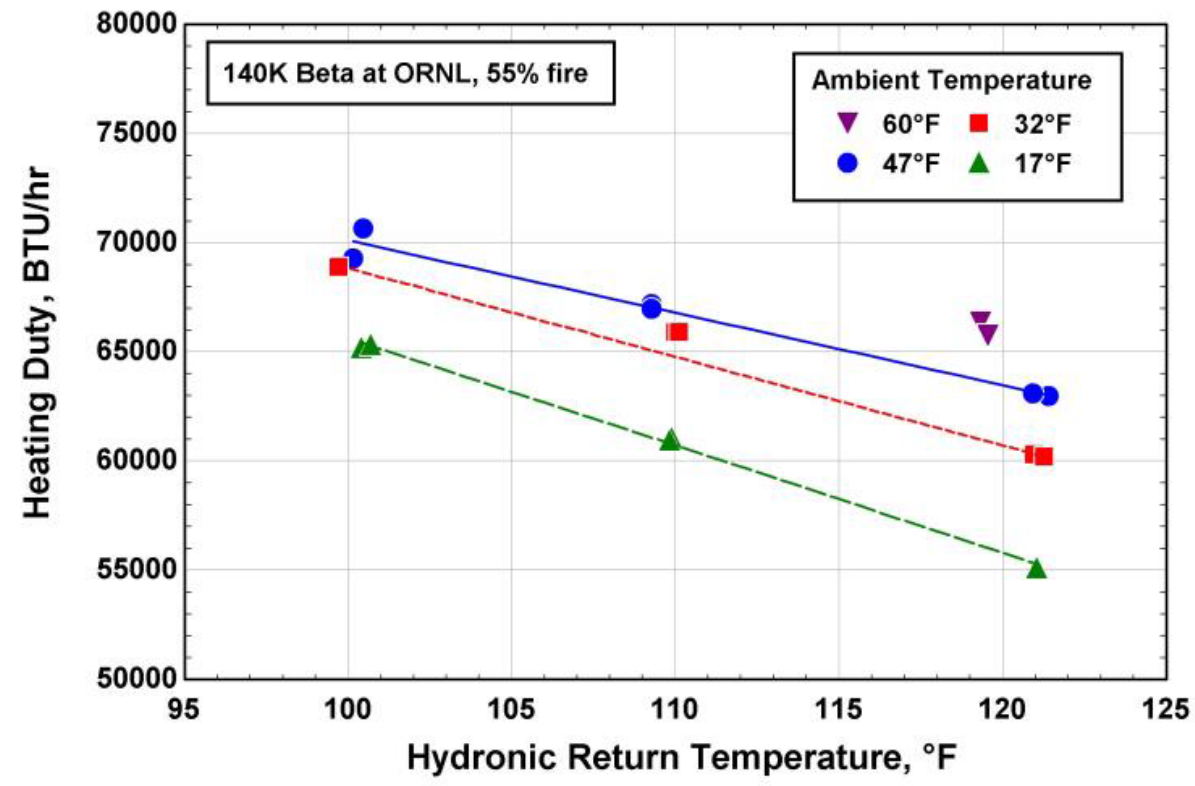

Figure 6. Heating load vs ambient air and hydronic inlet temperatures 


\section{FUTURE PLANS}

The Beta unit was returned to SMTI to undergo a thorough cleaning to remove any oil that contaminated the system during an incident with a vacuum pump at SMTI. The current rectifier will be removed and an alternative design (similar to the one used on the Breadboard system) will be investigated. Performance is expected to be much closer to design once the refrigerant purity is resolved. Implementation and testing of the desired defrost strategy will also be performed. A field test unit will be ready for testing early in 2017 

